\title{
Ovarian cancer immunotherapy: opportunities, progresses and challenges
}

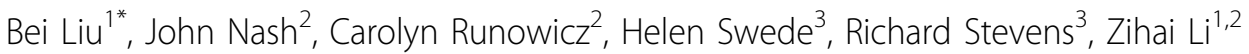

\begin{abstract}
Due to the low survival rates from invasive ovarian cancer, new effective treatment modalities are urgently needed. Compelling evidence indicates that the immune response against ovarian cancer may play an important role in controlling this disease. We herein summarize multiple immune-based strategies that have been proposed and tested for potential therapeutic benefit against advanced stage ovarian cancer. We will examine the evidence for the premise that an effective therapeutic vaccine against ovarian cancer is useful not only for inducing remission of the disease but also for preventing disease relapse. We will also highlight the questions and challenges in the development of ovarian cancer vaccines, and critically discuss the limitations of some of the existing immunotherapeutic strategies. Finally, we will summarize our own experience on the use of patient-specific tumor-derived heat shock protein-peptide complex for the treatment of advanced ovarian cancer.
\end{abstract}

\section{Introduction}

Ovarian cancer occurs with a lifetime incidence in approximately 1 in 58 women and it is the fifth leading cause of cancer death in women and is the leading cause of death among gynecologic cancers. It is estimated that approximately 21,550 new cases of ovarian cancer were diagnosed in 2009 in the United States with 14,600 deaths[1]. Sixty-seven percent of patients are diagnosed at stages III and IV, with resultant low relative-survival rates[1] despite, in many cases, apparently optimal surgery followed by the most effective combination chemotherapies available to date. Therefore, there is a compelling need for innovative and effective therapies.

Malignant tumors have been shown to be immunogenic in some cancer sites, including ovarian cancer. Some of the strongest evidence linking anti-tumor immunity and cancer have been made in ovarian cancer [2-5]. Understanding how the immune response is activated in ovarian cancer is a prerequisite for designing clinically meaningful immunologic strategies against this disease. Over the last two decades, there have been numerous clinical trials in ovarian cancer using immunologic modalities[6]. Results have been at best mixed, which demonstrates the need for a thoughtful and

\footnotetext{
* Correspondence: bliu@up.uchc.edu

'Department of Immunology, University of Connecticut School of Medicine, Farmington, USA
}

integrative approach to examine the role of immunotherapy in this disease. In this article, we will examine several key issues in this rapidly evolving area, highlighting the opportunities and challenges. We hope that our work will provide an overview and contribute to discovery the most effective immunotherapy of ovarian cancer.

\section{Historical Perspective: Is Cancer Immunogenic?}

Immunogenicity is the ability of antigens to elicit an immune response. It is well known that traditional vaccines can be very powerful in the prevention of infectious diseases such as smallpox. The early vaccines against smallpox, originating in China, were inspired by the concept of variolation. The term vaccine (adopted from the Latin vaccin-us, from vacca cow) derives from Edward Jenner's use of cow pox particulate, which was found to provide protection against smallpox when it was administered to humans around 1796 . Nearly 100 years ago, Paul Ehrlich proposed his theory of "immune surveillance", where tumor cells are rapidly eliminated by the immune system on a daily basis. This concept could not be tested at that time due to lack of appropriate models and in vitro systems. Even immunodeficient mouse models have failed to provide direct and definitive evidence supporting this theory[7].

The first cancer vaccine in human is attributed to William Coley in 1893[8]. He observed that some 
patients with cancer benefited from bacterial infection resulting in tumor shrinkage. This prompted him to treat the patients with bacterial extracts. This novel observation led many to conclude that the immune system can recognize tumor-associated antigens. Indirect or circumstantial evidences are now mounting supporting the existence of the cancer immunosurveillance mechanism in both animals and humans. However, cancer also adopts a variety of strategies to evade or suppress the immune system. The host-cancer interaction may or may not lead to tumor eradication. Thus the concept of "cancer immunosurveillance" is being replaced by the concept of "cancer immunoediting," which emphasizes a dynamic process of interaction between cancer and the immune system. Operationally, cancer immunoediting can be divided arbiturilly into three phases: elimination, equilibrium, and escape, highlighting the dynamic interaction between the host immune system and cancer. In the early phase of tumor initiation, immune response is effective, resulting in elimination of cancer. This is followed by a long period of equilibrium when cancer is not eliminated but it is kept in check by the immune system and is thus not clinically detectable. Cancer becomes clinically detectable when it has escaped effective anti-tumor immunity. This concept would predict that the immune system not only protects the host against the development of primary cancer, but also sculpts tumor immunogenicities, a process which has been experimentally confirmed[7].

Initially tumor antigens were broadly classified into two categories based on their pattern of expression: tumor-specific antigens (TSA), which are present only on tumor cells and not on any other cells; and tumorassociated antigens (TAA), which are present on some tumor cells and also some normal cells. However, this classification is imperfect because many antigens that were thought to be tumor-specific turned out to be expressed on some normal cells as well. The modern classification of tumor antigens is based on their molecular structure and source. Several techniques to identify tumor antigens have been developed, which include serological identification of antigens by recombinant cDNA expression cloning (SEREX)[9,10], T-cell epitope cloning (TEPIC), and bioinformatics[11]. A large array of immunogenic tumor antigens has been identified. Currently, human tumor antigens are classified into the following classes: differentiation antigens, overexpression/amplification antigens, mutational antigens, cancer testis antigens, oncofetal antigens, and viral antigens[6] (Table 1). Up to now, over 1,000 human tumor antigens have been established in a human cancer immunome database http://ludwig-sun5.unil.ch/CancerImmunomeDB/. This effort aims to enhance the opportunity for researchers in the cancer immunology field to design efficacious immunotherapy strategies through specificically targeted tumor antigens.

\section{Clinical Evidence for the Role of Immunosurveillance Against Human Ovarian Cancer}

Intratumoral T cells correlate with clinical outcome

The first evidence of the role of immunosurveillance against human ovarian cancer was the presence of tumor-infiltrating lymphocytes (TILs), which correlated positively and strongly with patient survival[2]. Zhang et al. (2003) performed immunohistochemical analyses to assess the distribution of TILs in 186 frozen specimens from stage III or IV ovarian cancers and conducted clinical outcome analyses. In this study, $\mathrm{CD}^{+}{ }^{+}$TILs were detected within tumor-cell islets in 102 of the 186 tumors $(54.8 \%)$, whereas $\mathrm{CD}^{+}$TILs were not detected in 72 of 186 tumors (38.7\%); 12 tumors could not be evaluated (6.5\%). They also assessed the number of CD4 ${ }^{+}$and $\mathrm{CD}^{+}{ }^{+} \mathrm{T}$ cells in 30 tumors, and the numbers of $\mathrm{CD}^{+}$and $\mathrm{CD}^{+} \mathrm{T}$ cells were closely correlated $\left(\mathrm{R}^{2}=0.66, \mathrm{p}<0.001\right)$. The immunohistochemical staining data showed that intratumoral $\mathrm{CD} 4^{+}$and $\mathrm{CD} 8^{+}$cells were either both present or both absent. Patients whose tumors contained TILs had five-year overall survival rates of $38 \%$, whereas patients whose tumors lacked TILs only had five-year overall survival rates of $4.5 \%$. The five-year progression-free survival rates for patients whose tumors were present and absent of TILs were $31.0 \%$ and $8.7 \%$ respectively. Thus, overall and progression-free five-year survival rates were significantly prolonged in the patients whose tumors contained TILs compared to the patients whose tumors did not contain TILs ( $\mathrm{p}<0.001$ for both comparisons). In a multivariate analysis, it was shown that the presence or absence of TILs $(p<0.001)$ and the extent of residual tumor $(p<0.001)$ correlated with overall and progression-free survival, but patient age ( $<55$ years vs. $>55$ years), tumor grade (grade 1 vs. grade 3 , grade 2 vs. grade 3 ), and type of first-line chemotherapy did not vary with outcomes [2].

Other studies have confirmed that the intraepithelial $\mathrm{CD}^{+}$TIL count is a significant prognostic factor in epithelial ovarian cancer (EOC). Tomšová et al. showed improved overall survival among 116 EOC patients with higher versus lower counts of intraepithelial $\mathrm{CD}^{+}{ }^{+}$TILs (> 60 vs. 29 months, respectively, $p<0.0001$ )[3].

\section{Predictable value of tumor infiltrating regulatory $\mathrm{T}$ cells}

Sato et al. performed immunohistochemical analyses for TILs in 117 cases of epithelial ovarian cancer. Patients with higher frequencies of intraepithelial $\mathrm{CD} 8^{+} \mathrm{T}$ cells demonstrated improved survival compared to patients with lower frequencies (55 vs. 26 months; hazard 
Table 1 Human Tumor-Associated Antigens*

\begin{tabular}{|c|c|c|c|c|}
\hline Antigen category & Antigens & Tumor type & Vaccine & Reference \\
\hline \multirow[t]{3}{*}{ Differentiation Antigens } & Tyrosinase & Melanoma & Yes & Int J Cancer 1996;67:54[60] \\
\hline & Melan- Mart-1 & Melanoma & Yes & Cancer J Sci Am 1997; 3:37[61] \\
\hline & gp-100 & Melanoma & Yes & Nat Med 1998; 4:321[62] \\
\hline $\begin{array}{l}\text { Overexpression/ } \\
\text { Amplification }\end{array}$ & HER-2/neu & Ovarian cancer Breast cancer & Yes & J Clin Oncol. 2002; 20:2624[13] \\
\hline Antigens & p53 & various tumors & Yes & $\begin{array}{l}\text { J Immunol 1998; 160:328[63] } \\
\text { Cancer Immunol Immunother. 2004; 53:633 } \\
\text { [64] }\end{array}$ \\
\hline \multirow[t]{2}{*}{ Mutational Antigens } & p53 & various tumors & Yes & J Clin Oncol 2005; 23:5099[65] \\
\hline & Ras & various tumors & Yes & Int J Cancer 2001; 92:441[66] \\
\hline \multirow[t]{3}{*}{ Cancer Testis Antigens } & MAGE & Melanoma & Yes & Int J Cancer 1999; 80:219[67] \\
\hline & NY-ESO-1 & Ovarian cancer & Yes & Clin Cancer Res. 2008; 14:2740[31] \\
\hline & LAGE-1 & $\begin{array}{l}\text { Ovarian cancer Melanoma Bladder } \\
\text { cancer }\end{array}$ & No & Cancer Res. 2003; 63:6076[20] \\
\hline \multirow[t]{2}{*}{ Glycolipid Antigens } & MUC-1 & Adenocarcinoma & Yes & J. Clin. Invest. 1997; 100:2783[68] \\
\hline & MUC-16 (CA125) & Ovarian cancer & Yes & $\begin{array}{l}\text { Int J Cancer 2002; 98:737[69] } \\
\text { Clin Cancer Res. 2004; 22:3507[70] }\end{array}$ \\
\hline \multirow[t]{3}{*}{ Oncofetal Antigens } & AFP & Germ cell tumors & No & Gynecol. Oncol. 2000; 77:203[71] \\
\hline & CEA & Colorectal cancer & Yes & Ann Surg Oncol 1996; 3:495[72] \\
\hline & PSA & Prostate cancer & Yes & Urology 1999; 53:260[73] \\
\hline Viral Antigens & HPV & Cervical cancer & Yes & Lancet 1996; 347:1523[74] \\
\hline
\end{tabular}

*This represents only a partial list of tumor antigens for immunotherapy.

ratio $=0.33 ; 95 \%$ C.I., $0.18-0.60 ; p=0.0003)$. In addition, the subgroups with high versus low intraepithelial $\mathrm{CD}^{+} / \mathrm{CD}^{+}{ }^{+}$TIL ratios had median survival rates of 74 months versus 25 months, respectively, with a corresponding hazard ratio of 0.30 (95\% C.I., 0.16-0.55; $p=$ $0.0001)$. These data indicate that $\mathrm{CD} 4^{+}$TILs influence the beneficial effects of $\mathrm{CD}^{+}$TIL. The unfavorable effect of $\mathrm{CD}^{+}{ }^{+} \mathrm{T}$ cells on prognosis is thought to be due to $\mathrm{CD}_{2} 5^{+}$forkhead box $\mathrm{P} 3(\mathrm{FOXP} 3)^{+}$regulatory $\mathrm{T}$ cells ( $\mathrm{T}_{\text {reg; }}$ suppressor $\mathrm{T}$ cells), as indicated by the survival of patients with high versus low $\mathrm{CD}^{+} / \mathrm{T}_{\text {reg }}$ ratios (58 versus 23 months; hazard ratio $=0.31$; $95 \%$ C.I., $0.17-0.58$; $p=0.0002$ )[4]. This observation strongly suggests that $\mathrm{CD}^{+}{ }^{+} \mathrm{CD} 25^{+} \mathrm{FOXP}^{+}$regulatory $\mathrm{T}$ cells within the tumor mass may suppress anti-tumor immunity.

Curiel et al. provided the first direct evidence that tumor associated $\mathrm{CD} 4^{+} \mathrm{CD} 25^{+} \mathrm{FOXP}^{+} \mathrm{T}_{\text {reg }}$ cells correlate to a poor clinical outcome in epithelial ovarian cancer (EOC)[5]. In this study, they revealed a substantial population of $\mathrm{CD} 4{ }^{+} \mathrm{CD} 25^{+} \mathrm{CD}^{+} \mathrm{T}$ cells $(10-17 \%$ of all $\mathrm{T}$ cells) in malignant ascites from 45 untreated EOC patients. $\mathrm{CD} 4{ }^{+} \mathrm{CD} 25^{+} \mathrm{CD}^{+} \mathrm{T}$ cells were concentrated much more in malignant ascites than in the peripheral blood and nonmalignant ascites (0.7-5.0\%). Using multicolor confocal microscopy, the study also found a substantial accumulation of $\mathrm{CD} 4{ }^{+} \mathrm{CD} 25^{+} \mathrm{CD}^{+} \mathrm{T}$ cells within the tumor mass among 104 tumor specimens from untreated EOC patients. The percentage of CD4 ${ }^{+} \mathrm{CD} 25^{+} \mathrm{CD}^{+} \mathrm{T}$ cells was higher in stage II-IV disease than in stage $\mathrm{I}$. In addition, $75 \%$ of $\mathrm{CD} 4^{+} \mathrm{CD} 25^{+} \mathrm{CD} 3^{+} \mathrm{T}$ cells were found in proximity to infiltrating $\mathrm{CD}^{+} \mathrm{T}$ cells, which indicated the possibility of inhibition through physical contact between $\mathrm{CD} 4^{+} \mathrm{CD} 25^{+} \mathrm{CD} 3^{+} \mathrm{T}$ cells and $\mathrm{CD}^{+} \mathrm{T}$ cells. Furthermore, they confirmed that $\mathrm{CD} 4{ }^{+} \mathrm{CD} 25^{+} \mathrm{CD}^{+} \mathrm{T}$ cells have characteristics of $\mathrm{T}_{\text {reg }}$ cells, which bear the surface phenotype of CD4 ${ }^{+} \mathrm{CD} 25^{+} \mathrm{CD}^{+}{ }^{+} \mathrm{GITR}^{+} \mathrm{CTLA} 4{ }^{+} \mathrm{CCR} 7{ }^{+} \mathrm{FOXP}^{\mathrm{hi}}$. These cells also suppressed the proliferation of $\mathrm{CD}^{+} \mathrm{CD} 25^{-} \mathrm{T}$ cells, as well as IFN- $\gamma$ and IL-2 production in vitro. Also, they found that $\mathrm{T}_{\text {regs }}$ preferred to accumulate in the tumor mass rather than in tumor-draining lymph nodes. Moreover, the $\mathrm{CD} 4^{+} \mathrm{CD} 25^{+} \mathrm{T}$ cells in tumor-draining lymph nodes declined from stage I to IV, suggesting they were preferentially recruited to the tumor mass. They also showed that tumor $\mathrm{T}_{\text {regs }}$ were associated with higher risk of death and reduced survival time. In multivariate 
analysis, individuals with the highest $\mathrm{T}_{\text {reg }}$ content experienced a 25.1-fold risk of death compared to those with the lowest $\mathrm{T}_{\text {reg }}$ content (95\% C.I., 6.8-92.1). After controlling for stage of disease and surgical debulking, tumor $\mathrm{T}_{\text {reg }}$ cells were a significant predictor for death and survival in ovarian cancer[5]. Another study showed that high FoxP3 mRNA expression in tumor samples from patients with invasive ovarian cancer had poorer overall survival (27.8 vs. 77.3 months, $p=0.0034$ ) and progression-free survival (18 vs. 57.5 months; $p=$ 0.0041) when compared with patients with lower FoxP3 mRNA expression.

In Cox multivariate regression analysis, FoxP3 high expression was an independent prognostic factor for both progression-free and overall survival $(p=0.004)$.

These studies strongly suggest that the immune response against ovarian cancer is a significant and independent prognostic factor. It highlights the possibility that favorable anti-ovarian cancer immune response could indeed result in improvement of the clinical outcome[12].

\section{Ovarian Cancer Immunotherapy as an Effective Treatment Modality: The Hypothesis}

Ovarian cancer of epithelial origin is an adenocarcinoma of the epithelial lining of the ovary. Because of the cryptic location of the ovary, ovarian cancer is usually diagnosed after regional or distant metastasis. The major cause of mortality is clinical relapse. Following standard surgery and chemotherapy, immunotherapy may boost the memory anti-tumor immune response to eradicate residual micrometastatic disease and to prevent relapse when given the consolidation therapy. Immunotherapy as a potential approach for treatment of ovarian cancer is based on the following evidence: (1) ovarian cancers express tumor-associated antigens, e.g. HER $2 /$ neu [13,14], MUC1[15], OA3[16], membrane folate receptor [17], TAG-72[18], mesothelin[19], NY-ESO-1[20], and sialyl-Tn[21], which can serve as targets for humoral and cellular immune responses; (2) the presence of TILs correlates strongly with survival[2]; (3) ovarian cancers express peptide/MHC complexes, which can be recognized by $\mathrm{CD}^{+} \mathrm{T}$ lymphocytes; (4) and most importantly, the dynamic interaction between host immunity and cancer indicate that the balance between the two forces can be tipped to favor the host immunity, with the ever increasing arsenals of the immunological nature. Taken together, it has been hypothesized that immunotherapy could be an innovative and effective supportive therapy for ovarian cancer.

\section{Clinical Trials of Immunotherapeutic Strategies Against Ovarian Cancer: the Opportunities}

Current immunotherapeutic treatment options for ovarian cancer include but are not limited to therapy with antibodies (Abs) for example against CA125 and idiotypic antibodies, cytokines (such as IFN $\gamma$, IL-2), active immunization with gene transduced whole tumor cells, peptide-based vaccines, dendritic cell vaccines and heat shock protein (HSP) vaccines. These modalities are at different phases of clinical investigation and, currently, are not the standard of care. Key clinical studies are summarized in Table 2, some of which we describe in more detail below. Strengths and limitations of approaches are listed in Table 3.

\section{Antibody-based vaccines}

Antibody-based cancer immunotherapy has now become a standard practice in the treatment of lymphoma and other cancers. CA-125, also known as MUC16 is a wellstudied ovarian cancer antigen which was initially identified by Bast, et al. in 1981[22]. CA-125 is a surface glycoprotein antigen, which is elevated in $79 \%$ of all patients with ovarian cancer[23] and in 95\% of patients with stages III and IV ovarian cancer[24].

Oregovomab (Mab B43.13) is a murine monoclonal antibody that binds to CA-125 with high affinity and can induce both humoral and cellular immune responses against ovarian cancer. Ehlen et al. performed a pilot phase II study to examine the immunologic and clinical effect of oregovomab in pretreated patients with recurrent ovarian cancer[25]. More than $50 \%$ of patients were successfully induced to generate an anti-CA125 antibody as well as CA125 or oregovomab-specific T cells. Three of thirteen patients had stabilization of disease and survival for more than 2 years. In another phase II trial, the combination of chemotherapy and oregovomab in 20 patients with recurrent epithelial ovarian cancer was studied[26]. Fifteen out of the nineteen patients $(79 \%)$ developed humoral responses, including human anti-mouse antibodies and antibodies against oregovomab. Two patients $(11 \%)$ developed antiCA125 antibodies, whereas 7 of 18 (39\%) patients produced CA125 specific T cells. In 5 of 8 (63\%) patients, $\mathrm{T}$ cell response was specific for autologous tumor, and in 9 of $18(50 \%)$ patients, the $\mathrm{T}$ cell response was directed against oregovomab. Patients who had a T-cell immune response showed significantly improved survival.

In addition, many investigators have attempted to use an anti-idiotype antibody to increase immunogenicity. Based on Jerne's network theory, immunization with a given antigen will generate specific antibodies against the antigen (termed Ab1). Ab1 can generate anti-idiotypic antibodies against Ab1, termed Ab2. Some of the anti-idiotypic antibodies (Ab2 $\beta)$ express the internal image of the antigen recognized by the Ab1 antibody and can thus be used as surrogate antigens. Immunization with Ab2 $\beta$ could lead to the development of anti- 
Table 2 Findings from Clinical Trials of Immunotherapy for Ovarian Cancer

\begin{tabular}{|c|c|c|c|c|}
\hline Strategies & Phase & Immune response & Clinical response & Reference \\
\hline \multicolumn{5}{|l|}{ Antibody-based vaccine } \\
\hline $\begin{array}{l}\text { Anti-CA125 (Oregovomab MAb } \\
\text { B43.13) }\end{array}$ & $|/| \mid$ & Increased Ag specific T cells & Improved survival & {$[25,26,75,76]$} \\
\hline Anti-idiotype Ab (ACA-125) & $|/| \mid$ & $\begin{array}{l}\text { Induced Ab3, Ab1 and ADCC of } \mathrm{CA}_{125^{+}} \text {tumor } \\
\text { cells }\end{array}$ & Improved survival & {$[28,77]$} \\
\hline $\begin{array}{l}\text { Anti-HER-2 (trastuzumab, } \\
\text { pertuzumab) }\end{array}$ & $|/| \mid$ & $N R^{*}$ & $\begin{array}{l}\text { Stable disease for more than } 2.5 \\
\text { months }\end{array}$ & {$[78,79]$} \\
\hline $\begin{array}{l}\text { Anti-MUC-1 idiotypic Ab } \\
\text { (HMFG1) }\end{array}$ & $|/| \mid$ & Induced Humoral Immune Responses & Prolonged survival & {$[80,81]$} \\
\hline \multicolumn{5}{|l|}{ Peptide vaccine } \\
\hline HER2/neu & $|/| \mid$ & $\begin{array}{l}\text { Developed humoral and T cell immune } \\
\text { Response }\end{array}$ & $N R^{*}$ & {$[13,14]$} \\
\hline NY-ESO-1 & 1 & $\begin{array}{l}\text { Induced both humoral and cellular immune } \\
\text { responses }\end{array}$ & $N R^{*}$ & {$[82,83]$} \\
\hline \multicolumn{5}{|l|}{ Cytokine vaccine } \\
\hline IL-2 & $|/| \mid$ & $N R^{*}$ & Prolonged survival & [84] \\
\hline IFN- $\alpha$ & $|/| \mid$ & $N R^{*}$ & $\begin{array}{l}20 \% \text { complete and } 8 \% \text { partial } \\
\text { response }\end{array}$ & {$[85-87]$} \\
\hline IFN- $\gamma$ & I & $\begin{array}{l}\text { Increased cytotoxity against tumor associated } \\
\text { macrophages }\end{array}$ & $N R^{*}$ & {$[32,88,89]$} \\
\hline \multicolumn{5}{|l|}{ Tumor cell vaccine } \\
\hline Whole tumor cells & I & CD8 T-cell response & No clinical response & [33] \\
\hline $\begin{array}{l}\text { Tumor cells transfected with GM- } \\
\text { CSF }\end{array}$ & I & $N R^{*}$ & Improve survival & {$[34]$} \\
\hline \multicolumn{5}{|l|}{ Dendritic cell vaccine } \\
\hline $\begin{array}{l}\text { DC pulse with autologous tumor } \\
\text { antigen }\end{array}$ & I & DTH & $N R^{*}$ & {$[90]$} \\
\hline DC pulse with mRNA of FR- $\alpha$ & & CD4+ and CD8+ T-cell responses & $N R^{*}$ & [91] \\
\hline DC/tumour-fusion vaccine & $\begin{array}{l}\text { Pre-clinical } \\
\text { trial }\end{array}$ & Elevated serum levels of ANA & $N R^{*}$ & [92] \\
\hline DC pulse with peptide & $\begin{array}{l}\text { Pre-clinical } \\
\text { trial }\end{array}$ & $C T L$ & $N R^{*}$ & [43] \\
\hline \multicolumn{5}{|l|}{ HSP vaccine } \\
\hline Gp96 & I & Increased NK cell activity & & $\begin{array}{l}\text { [unpublished } \\
\text { data] }\end{array}$ \\
\hline
\end{tabular}

* Not reported

Table 3 Summary of the Strengths and Limitations of Ovarian Cancer Immunotherapy

\begin{tabular}{lll}
\hline Strategies & Pros & Cons \\
\hline Antibody-based vaccine & Tumor antigen specific. Easy to produce. & Weak immunogenicity. Not for all individuals. \\
Peptide vaccine & Safe, stable, and easy to produce and modify. & Poor immunogenicity. HLA restriction. \\
Cytokine vaccine & Easy to manufacture and administer. & Non-specific immunomodulating only. \\
Tumor cell vaccine & Convenience, contained tumor antigen pool. & Potential safety concern. Difficult to produce. \\
& Powerful professional antigen presenting cells. May prime both T T & Difficult to standardize. \\
Dendritic cell vaccine & cells and antibody response. & Difficult to manufacture and standardize. \\
HSP vaccine & May contain multiple antigens. & No data on ovarian cancer yet \\
Immunomodulation with & Promising strategy & Difficult to completely eliminate Treg. \\
Treg blockage & &
\end{tabular}


anti-idiotype antibodies (termed Ab3) that recognize the corresponding original antigen identified by Ab1[27]. Abagovomab (formerly ACA-125) is a mouse anti-idiotype monoclonal antibody whose variable epitope mirrors CA-125. In a phase I/IIb study, 119 patients with advanced ovarian cancer were treated with abagovomab. A specific anti-anti-idiotypic antibody (Ab3) was induced in 81 patients (68.1\%). Fifty percent of patients developed a specific anti-CA125 antibody and $26.9 \%$ of patients were found to have antibody-dependent cellmediated cytotoxicity of CA125-positive tumor cells. The median survival rate of all patients was 19.4 months (range: 0.50-56 months). However, Ab3-positive patients showed a significantly longer survival rate (median, 23.4 months; $\mathrm{p}<0.0001$ ) compared with Ab3-negative patients (median, 4.9 months)[28]. A second Phase I trial of abagovomab, consisting of 36 patients with recurrent ovarian cancer, compared 9 applications (group L) with 6 applications (group S). Ab3 was induced in all evaluable patients. A more than twofold increase of IFN- $\gamma$-expression CA125-specific CD $8^{+} \mathrm{T}$ cells was observed at least once during the immunization in 9 of $12(75 \%)$ patients of group L and 3 of 17 $(17.6 \%)$ of group $S(p=0,006)$. However, there was no consistent correlation between the induction of $\mathrm{Ab} 3$ and frequencies of CA125-specific CTL and T helper cells [29].

HMFG1 is a murine monoclonal antibody with specificity to MUC1, a cell surface glycoprotein that is expressed by more than $90 \%$ of epithelial ovarian cancer and other tumors. In a phase I/II study, 52 patients with epithelial ovarian cancer were treated with yttrium-90labelled monoclonal antibody HMFG1 administered intraperitoneally. After the completion of conventional surgery and chemotherapy, 21 of the 52 patients had no evidence of residual disease. These data suggest that the survival of patients who received the intraperitoneal antibody was prolonged compared to that of historical controls[30].

\section{Peptide vaccines}

Using peptide as immunogens for immunotherapy has many advantages, since peptides are well defined and the risk for sharing with normal cellular proteins can be minimized. In addition, peptide antigens are easy to manufacture, stable, and can be modified to increase their immunogenicity. However, peptide vaccines usually have poor immunogenicity and need to be administered with adjuvants such as GM-CSF. Disis and her colleagues have performed multiple phase I/II clinical trials using HER2 derived peptides for the treatment of patients with HER2 overexpressing tumors. Consistent HER2-specific T cell response was generated. Moreover, epitope spreading was seen in some patients. The magnitude of the $\mathrm{T}$ cell response appears to correlate favorably with the clinical response[13].

NY-ESO-1, another promising cancer-testis antigen, is expressed by more than $40 \%$ of advanced epithelial ovarian cancers. Diefenbach et al. performed a phase I study to evaluate the effects of vaccination with the HLA-A0201-restricted NY-ESO-1b peptide on patients with high-remission-risk epithelial ovarian cancer, and found that the NY-ESO-1 peptide-based vaccine was safe and induced specific T-cell immunity in both NYESO-1 positive and NY-ESO-1 negative patients[31].

\section{Cytokine vaccines}

Exogenously supplied cytokines provide immune regulation and maximize the induction, amplification, and/or effector properties of the desirable immune response in the microenvironment of the vaccination site. Combinations of cytokines and chemotherapeutic agents have been tested against ovarian cancer. For example, Schmeler et al. from MD Anderson Cancer Center have recently reported the completion of a phase II study to evaluate the efficacy and toxicity of carboplatin, granulocyte-macrophage colony-stimulating factor (GM-CSF) and recombinant interferon gamma $1 \mathrm{~b}(\mathrm{rIFN}-\gamma 1 \mathrm{~b})$ in women with recurrent and platinum-sensitive ovarian, fallopian tube and primary peritoneal cancer[32]. Eligible patients were treated with subcutaneous GM-CSF and rIFN- $\gamma 1 \mathrm{~b}$ before and after intravenous carboplatin until disease progression or unacceptable toxicity. All patients had measurable disease and a chemotherapy-free interval greater than 6 months. Fifty-nine patients received a median of 6 cycles of therapy (range, 1 to 13 cycles). Median age at enrollment was 61 years (range, 35 to 79 years). Median time to progression prior to enrollment was 11 months (range, 6 to 58 months). Of the 54 patients evaluable for response, 9 (17\%) had a complete response, 21 (39\%) had a partial response, and 24 (44\%) exhibited progressive disease. The overall response rate was $56 \%$ (95\% CI: $41 \%$ to $69 \%$ ). With a median followup of 6.4 months, median time to progression was 6 months. Myeloid derived cells and platelets increased on day 9 of each chemotherapy cycle. The most common adverse effects were bone marrow suppression, carboplatin hypersensitivity, and fatigue. Responders reported improved quality of life. Although it is difficult to evaluate the clinical efficacy in the phase II setting, the safety profile and encouraging response warrant further study of this approach.

\section{Tumor cell vaccines}

In the absence of known tumor antigens, whole tumor cell vaccines offer a simple way to prepare the vaccine which contains a broad tumor antigen repertoire. But whole tumor cells are poorly immunogenic due to their 
lack of immunostimulatary signals. In order to increase immunogenicity, the whole tumor cell vaccines need to be associated with a specific adjuvant. In a phase I trial, Berd et al. modified autologous cancer cells with the hapten, dinitrophenyl (DNP). Administration of the DNP-tumor cell vaccine to patients with metastatic melanoma induced inflammation in metastatic sites. Histologically, most of the infiltration of $\mathrm{T}$ lymphocytes were $\mathrm{CD}^{+}$cells[33]. Investigators have tried to modify tumor cell vaccines by transducing GM-CSF into tumor cells. Nemunaitis et al. conducted a phase I/II multicenter trial in patients with early and advanced stage nonsmall-cell lung cancer. Vaccines were successfully manufactured for 67 patients, and 43 were vaccinated. Survival in patients receiving vaccines secreting higher amounts of GM-CSF (median survival = 17 months, 95\% CI; 6 to 23 months) was significantly longer than in patients receiving vaccines secreting less GM-CSF (median survival $=7$ months, $95 \% \mathrm{CI}$; 4 to 10 months $)(\mathrm{p}=$ 0.028)[34].

\section{Dendritic cell vaccines}

Dendritic cells (DCs) are major professional antigen-presenting cells which control primary and secondary immune responses to various exogenous antigens through antigen cross-presentation and cross-priming of $\mathrm{T}$ cells $[35,36]$. DCs also play important roles in establishing anti-tumor immunity and autoimmunity [37-39], both of which are immune responses to self-antigens through the breakdown of immune tolerance. Because DCs have a potential to induce antigen-specific antitumor immunity, several clinical trials of cancer immunotherapy using DC vaccines have been performed [40,41]. Gong et al. used a tumor cell/DC fusion strategy[42]. In this study, human ovarian cancer cells were fused to human DCs, and they found that the fused cells were functional in stimulating the proliferation of autologous $\mathrm{T}$ cells, inducing cytolytic $\mathrm{T}$ cell activity and the lysis of autologous tumor cells by a MHC class Irestricted mechanism[42]. Brossart et al. treated patients with advanced breast and ovarian cancer with autologous DCs pulsed with HER-2/neu- or MUC1-derived peptides. In 5 of $10(50 \%)$ patients, peptide-specific cytotoxic $\mathrm{T}$ lymphocytes (CTLs) were generated after vaccination. The major CTL response in vivo was induced with the HER-2/neu-derived E75 and MUC1-derived M1.2 peptide. The DC vaccinations were well tolerated with minimal side effects[43].

\section{Heat shock protein vaccines}

HSPs are best known as molecular chaperones, which play vital roles in assisting protein folding[44]. A number of mammalian HSPs (gp96, HSP90, HSP70, calreticulin, HSP110, grp170), when isolated from tumor cells, have been shown to elicit tumor-specific immunity, and when isolated from virus-infected cells, have been demonstrated to elicit virus-specific immunity $[45,46]$. The immunity in each case is specific to the individual tumor (or virus-infected cell) that was used as the source of the HSP preparation. A large number of clinical trials have been carried out to determine if tumorderived HSP preparations are able to elicit tumor-specific immunities. Results from human clinical trials in our institution and others in melanoma, renal cell cancer, chronic myelogenous leukemia and other diseases are consistent with the murine experience [47-50].

The effects of HSPs against a wide spectrum of cancers, across species, appear to be related to three key features: (1) HSPs that are isolated from cancer cells, although pure and homogenous, are bound to a wide array of peptides, including antigenic tumor-specific peptides. Therefore, pure HSPs isolated from a tumor cell also contain the entire antigenic peptides from this cell[46]. (2) HSP-peptide complexes can interact with a conserved receptor molecule CD91 on the surface of DCs[51]. These complexes are internalized by DCs, and the peptides that were chaperoned by HSPs are crosspresented by MHC I molecules of the DCs. These MHC I-peptide complexes now stimulate naïve $\mathrm{CD} 8^{+} \mathrm{T}$ cells that mediate the anti-tumor activity. (3) HSP-DC interaction also leads to the activation of DCs, resulting in the production of proinflammatory cytokines and upregulation of co-stimulatory molecules which are necessary for the activation of $\mathrm{T}$ cell responses[46].

Our laboratory conducted a pilot study on the roles of the autologous ovarian cancer-derived gp96-peptide complex in the treatment of patients with stage III and IV ovarian cancer in the consolidation setting[52]. We hypothesized that effective immune intervention at the time of minimal residual disease is the ideal means to prevent relapses of this disease. Patients who completed the standard therapy with no disease progression were eligible to receive the vaccine. Seven patients (6 with stage IIIc disease, 1 with stage IIIb cancer) completed the gp96 injection at $25 \mu \mathrm{g}$ i.d., weekly for 8 weeks. Grade II or higher toxicity was not observed. No clinical evidence of autoimmunity was found. Five out of seven patients showed increased frequency of IFN $\gamma$-producing cells in the peripheral blood against gp96-pulsed autologous antigen-presenting cells (APCs) that are MHC class I-dependent. Of interest, 6 out of 7 patients demonstrated increased NK cell activity, measured by IFN $\gamma$ ELISPOT against NK cell target K562 cells. This finding is consistent with our prior study that demonstrated a significant increase of NK cell activity in patients with chronic myeloid leukemia (CML) after vaccination with HSP70, which led us to hypothesize that HSPs are able to mediate NK-DC cross-talk[49,53]. 
Our results demonstrated that a HSP-based vaccine is feasible, well tolerated and is able to induce favorable immune responses against ovarian cancer.

\section{What are the Challenges for Ovarian Cancer Immunotherapy?}

Although various immunotherapeutic approaches have been examined for the treatment of ovarian cancer, it remains true that no such therapy has entered into the clinical standard of care. Below we outline several challenges that need to be overcome.

When patients are diagnosed with cancer, by definition, the tumor has "escaped" the immune system, having passed the phases of "elimination" and "equilibrium". Although there is no shortage of ovarian cancer antigens due to genomic instability and accumulation of mutated genes at this point, the generation of immune response against these antigens is likely unproductive in the late stage, due to multiple immune tolerance mechanisms such as Treg infiltration in the tumor bed, general immune suppression from immunosuppressive cytokines by tumor cells, and down-regulation of MHC class I molecules on the tumor cells. Also, myeloid-derived suppressor cells (MDSC) and tumor-associated macrophages (TAM) create an immunosuppressive environment that leads to suppress $\mathrm{T}$ cell responses [54-56]. Thus, multiple immunological "brakes" need to be lifted to augment productive immune response. Currently, clinical studies examine one parameter at a time, which is perhaps too little too late. Combined immunotherapeutic modalities need to be seriously considered in order to break the "glass is half empty" reality of the current immunotherapy landscape in the treatment of ovarian cancer.

There are also practical challenges. It is an unclear and certainly not a trivial question to ask how immunotherapy shall be incorporated into conventional therapy. Surgery and chemotherapy are all seriously immunosuppressive at certain circumstances $[57,58]$, making them very difficult to combine with immunotherapy. Hence, the field is moving toward immunological intervention of patients after the completion of conventional therapy. One bold question is whether or not immunotherapy shall be moved up front, to be followed by surgery and chemotherapy. This seemingly counter-intuitive idea is founded on the premise that antigen-specific memory cells might well withstand conventional chemotherapy. Better yet, cancer vaccines should ideally be given to women in the high-risk category who have not yet been diagnosed with clinical cancer, during the "equilibrium" phase. This last scenario also depends, in part, on the ability of the medical field to screen and diagnose ovarian cancer much earlier than we are currently able to achieve. Lastly, it is worthwhile to reiterate that combined immunological modalities may be the best way to move forward. This approach demands the collaboration of investigators and the creativity of regulatory agencies such as the FDA for approval of novel combinations of various approaches in situations where none of these approaches alone has been shown to be effective yet.

\section{Conclusion and Perspectives}

In light of highly promising advancements in the science of immunotherapy against ovarian cancer coupled with encouraging results from numerous clinical trials, we suggest that bold steps need to be taken to further this area of research. First, a more permissive regulatory climate is needed to allow investigators to combine various non-proven modalities in hopes of finding an effective combination. Second, we should focus on finding biomarkers for early diagnosis or prognosis and individual treatment. Serum proteomics applications could identify blood-based biomarkers for early diagnosis and prognosis[59], and tissue proteomics could help to define targets for individualized treatment. Third, we should debate the merits to move immune intervention ahead of conventional therapy or even to high-risk patients in the prophylactic setting. Finally, resources and funding must be given to support the important translational groundwork by cancer immunologists and physician scientists. Without these critical steps, we might face the same uncertainty about therapy against this dreadful disease for years to come.

\section{Acknowledgements}

We thank University of Connecticut Health Center, Master of Public Health Program, Department of Immunology and Neag Comprehensive Cancer Center. B.L. was partly supported by Connecticut Stem Cell grant. Z.L. was supported by the National Institutes of Health grants and the Leukemia and Lymphoma Society.

\section{Author details}

'Department of Immunology, University of Connecticut School of Medicine, Farmington, USA. ${ }^{2}$ Neag Comprehensive Cancer Center, University of Connecticut School of Medicine, Farmington, USA. ${ }^{3}$ Department of Community Medicine \& Health Care, University of Connecticut School of Medicine, Farmington, USA.

\section{Authors' contributions}

BL participated in literature review and wrote the manuscript. BL, HS, RS, ZL conceived the concept. JN, CR, ZL, BL contributed the phase I trial data for heat shock protein vaccine. All authors participated in revising the manuscript and approved the final manuscript

\section{Competing interests}

The authors declare that they have no competing interests.

Received: 2 December 2009

Accepted: 10 February 2010 Published: 10 February 2010 


\section{References}

1. Horner MJRL, Krapcho M, Neyman N, Aminou R, Howlader N, Altekruse SF, Feuer EJ, Huang L, Mariotto A, Miller BA, Lewis DR, Eisner MP, Stinchcomb DG, Edwards BK, eds: SEER Cancer Statistics Review. 1975.

2. Zhang L, Conejo-Garcia JR, Katsaros D, Gimotty PA, Massobrio M, Regnani G, Makrigiannakis A, Gray H, Schlienger K, Liebman MN, et al: Intratumoral T cells, recurrence, and survival in epithelial ovarian cancer. N Engl J Med 2003, 348:203-213.

3. Tomsova M, Melichar B, Sedlakova I, Steiner I: Prognostic significance of CD3+ tumor-infiltrating lymphocytes in ovarian carcinoma. Gynecol Oncol 2008, 108:415-420

4. Sato E, Olson SH, Ahn J, Bundy B, Nishikawa H, Qian F, Jungbluth AA, Frosina D, Gnjatic S, Ambrosone C, et al: Intraepithelial CD8+ tumorinfiltrating lymphocytes and a high $\mathrm{CD} 8+$ /regulatory $\mathrm{T}$ cell ratio are associated with favorable prognosis in ovarian cancer. Proc Natl Acad Sci USA 2005, 102:18538-18543.

5. Curiel TJ, Coukos G, Zou L, Alvarez X, Cheng P, Mottram P, EvdemonHogan M, Conejo-Garcia JR, Zhang L, Burow M, et al: Specific recruitment of regulatory $T$ cells in ovarian carcinoma fosters immune privilege and predicts reduced survival. Nat Med 2004, 10:942-949.

6. Chu CS, Kim SH, June CH, Coukos G: Immunotherapy opportunities in ovarian cancer. Expert Rev Anticancer Ther 2008, 8:243-257.

7. Dunn GP, Old $L$, Schreiber RD: The three Es of cancer immunoediting Annu Rev Immunol 2004, 22:329-360.

8. Coley WB: The treatment of malignant tumors by repeated inoculations of erysipelas. With a report of ten original cases. 1893. Clin Orthop Relat Res 1991, 3-11.

9. Vaughan $\mathrm{H}$ : The humoral immune response to head and neck cancer antigens as defined by the serological analysis of tumor antigens by recombinant cDNA expression cloning. Cancer Immunity 2004, 4:5-20.

10. Sahin U, Tureci O, Schmitt H, Cochlovius B, Johannes T, Schmits R, Stenner F, Luo G, Schobert I, Pfreundschuh M: Human neoplasms elicit multiple specific immune responses in the autologous host. Proc Natl Acad Sci USA 1995, 92:11810-11813.

11. Odunsi K, Sabbatini P: Harnessing the immune system for ovarian cancer therapy. Am J Reprod Immunol 2008, 59:62-74.

12. Wolf $D$, Wolf $A M$, Rumpold $H$, Fiegl $H$, Zeimet $A G$, Muller-Holzner $E$, Deibl M, Gastl G, Gunsilius E, Marth C: The expression of the regulatory T cell-specific forkhead box transcription factor FoxP3 is associated with poor prognosis in ovarian cancer. Clin Cancer Res 2005, 11:8326-8331.

13. Disis ML, Gooley TA, Rinn K, Davis D, Piepkorn M, Cheever MA, Knutson KL, Schiffman K: Generation of T-cell immunity to the HER-2/neu protein after active immunization with HER-2/neu peptide-based vaccines. J Clin Oncol 2002, 20:2624-2632.

14. Disis ML, Goodell V, Schiffman K, Knutson KL: Humoral epitope-spreading following immunization with a HER-2/neu peptide based vaccine in cancer patients. J Clin Immunol 2004, 24:571-578.

15. Vlad AM, Kettel JC, Alajez NM, Carlos CA, Finn OJ: MUC1 immunobiology: from discovery to clinical applications. Adv Immunol 2004, 82:249-293.

16. Kenemans P: CA 125 and OA 3 as target antigens for immunodiagnosis and immunotherapy in ovarian cancer. Eur J Obstet Gynecol Reprod Biol 1990, 36:221-228.

17. Coliva A, Zacchetti A, Luison E, Tomassetti A, Bongarzone I, Seregni E, Bombardieri E, Martin F, Giussani A, Figini M, Canevari S: 90Y Labeling of monoclonal antibody MOv18 and preclinical validation for radioimmunotherapy of human ovarian carcinomas. Cancer Immunol Immunother 2005, 54:1200-1213.

18. Rosenblum MG, Verschraegen CF, Murray JL, Kudelka AP, Gano J, Cheung L, Kavanagh JJ: Phase I study of 90Y-labeled B72.3 intraperitoneal administration in patients with ovarian cancer: effect of dose and EDTA coadministration on pharmacokinetics and toxicity. Clin Cancer Res 1999, 5:953-961

19. Chang K, Pastan I: Molecular cloning of mesothelin, a differentiation antigen present on mesothelium, mesotheliomas, and ovarian cancers. Proc Natl Acad Sci USA 1996, 93:136-140.

20. Odunsi $K$, Jungbluth AA, Stockert E, Qian F, Gnjatic S, Tammela J, Intengan M, Beck A, Keitz B, Santiago D, et al: NY-ESO-1 and LAGE-1 cancer-testis antigens are potential targets for immunotherapy in epithelial ovarian cancer. Cancer Res 2003, 63:6076-6083.

21. Sandmaier BM, Oparin DV, Holmberg LA, Reddish MA, MacLean GD, Longenecker BM: Evidence of a cellular immune response against sialyl-
Tn in breast and ovarian cancer patients after high-dose chemotherapy, stem cell rescue, and immunization with Theratope STn-KLH cancer vaccine. J Immunother 1999, 22:54-66.

22. Bast RC Jr, Feeney M, Lazarus H, Nadler LM, Colvin RB, Knapp RC: Reactivity of a monoclonal antibody with human ovarian carcinoma. J Clin Invest 1981, 68:1331-1337.

23. Rosen DG, Wang L, Atkinson JN, Yu Y, Lu KH, Diamandis EP, Hellstrom I, Mok SC, Liu J, Bast RC Jr: Potential markers that complement expression of CA125 in epithelial ovarian cancer. Gynecol Oncol 2005, 99:267-277.

24. Bast RC Jr, Siegal FP, Runowicz C, Klug TL, Zurawski VR Jr, Schonholz D, Cohen CJ, Knapp RC: Elevation of serum CA 125 prior to diagnosis of an epithelial ovarian carcinoma. Gynecol Oncol 1985, 22:115-120.

25. Ehlen TG, Hoskins PJ, Miller D, Whiteside TL, Nicodemus CF, Schultes BC, Swenerton KD: A pilot phase 2 study of oregovomab murine monoclonal antibody to CA125 as an immunotherapeutic agent for recurrent ovarian cancer. Int J Gynecol Cancer 2005, 15:1023-1034.

26. Gordon AN, Schultes BC, Gallion H, Edwards R, Whiteside TL, Cermak JM, Nicodemus CF: CA125- and tumor-specific T-cell responses correlate with prolonged survival in oregovomab-treated recurrent ovarian cancer patients. Gynecol Oncol 2004, 94:340-351.

27. Jerne NK: Towards a network theory of the immune system. Ann Immunol (Paris) 1974, 125C:373-389.

28. Reinartz S, Kohler S, Schlebusch H, Krista K, Giffels P, Renke K, Huober J, Mobus V, Kreienberg R, DuBois A, et al: Vaccination of patients with advanced ovarian carcinoma with the anti-idiotype ACA125: immunological response and survival (phase Ib/II). Clin Cancer Res 2004 10:1580-1587.

29. Pfisterer J, du Bois A, Sehouli J, Loibl S, Reinartz S, Reuss A, Canzler U, Belau A, Jackisch C, Kimmig R, et al: The anti-idiotypic antibody abagovomab in patients with recurrent ovarian cancer. A phase I trial of the AGO-OVAR. Ann Oncol 2006, 17:1568-1577.

30. Hird V, Maraveyas A, Snook D, Dhokia B, Soutter WP, Meares C, Stewart JS, Mason $\mathrm{P}$, Lambert HE, Epenetos AA: Adjuvant therapy of ovarian cancer with radioactive monoclonal antibody. $\mathrm{Br} J$ Cancer 1993, 68:403-406.

31. Diefenbach CS, Gnjatic S, Sabbatini P, Aghajanian C, Hensley ML, Spriggs DR, lasonos A, Lee H, Dupont B, Pezzulli S, et al: Safety and immunogenicity study of NY-ESO-1b peptide and montanide ISA-51 vaccination of patients with epithelial ovarian cancer in high-risk first remission. Clin Cancer Res 2008, 14:2740-2748.

32. Schmeler KM, Vadhan-Raj S, Ramirez PT, Apte SM, Cohen L, Bassett RL Iyer RB, Wolf JK, Levenback CL, Gershenson DM, Freedman RS: A phase ॥ study of GM-CSF and rIFN-gamma1b plus carboplatin for the treatment of recurrent, platinum-sensitive ovarian, fallopian tube and primary peritoneal cancer. Gynecol Oncol 2009, 113:210-215.

33. Berd D, Kairys J, Dunton C, Mastrangelo MJ, Sato T, Maguire HC Jr: Autologous, hapten-modified vaccine as a treatment for human cancers. Semin Oncol 1998, 25:646-653.

34. Nemunaitis J, Sterman D, Jablons D, Smith JW, Fox B, Maples P, Hamilton S, Borellini F, Lin A, Morali S, Hege K: Granulocyte-macrophage colonystimulating factor gene-modified autologous tumor vaccines in nonsmall-cell lung cancer. J Natl Cancer Inst 2004, 96:326-331.

35. Steinman RM: The dendritic cell system and its role in immunogenicity. Annu Rev Immunol 1991, 9:271-296.

36. Banchereau J, Steinman RM: Dendritic cells and the control of immunity. Nature 1998, 392:245-252.

37. Steinman RM, Banchereau J: Taking dendritic cells into medicine. Nature 2007, 449:419-426

38. Dhodapkar MV, Dhodapkar KM, Palucka AK: Interactions of tumor cells with dendritic cells: balancing immunity and tolerance. Cell Death Differ 2008, 15:39-50.

39. Ludewig B, Odermatt B, Landmann S, Hengartner H, Zinkernagel RM: Dendritic cells induce autoimmune diabetes and maintain disease via de novo formation of local lymphoid tissue. J Exp Med 1998, 188:1493-1501

40. Steinman RM, Dhodapkar M: Active immunization against cancer with dendritic cells: the near future. Int J Cancer 2001, 94:459-473.

41. Lopez JA, Hart DN: Current issues in dendritic cell cancer immunotherapy. Curr Opin Mol Ther 2002, 4:54-63.

42. Gong J, Nikrui N, Chen D, Koido S, Wu Z, Tanaka Y, Cannistra S, Avigan D, Kufe D: Fusions of human ovarian carcinoma cells with autologous or 
allogeneic dendritic cells induce antitumor immunity. J Immunol 2000, 165:1705-1711.

43. Brossart P, Wirths S, Stuhler G, Reichardt VL, Kanz L, Brugger W: Induction of cytotoxic T-lymphocyte responses in vivo after vaccinations with peptide-pulsed dendritic cells. Blood 2000, 96:3102-3108.

44. Lindquist S, Craig EA: The heat-shock proteins. Annu Rev Genet 1988, 22:631-677.

45. Li Z: Priming of T cells by heat shock protein-peptide complexes as the basis of tumor vaccines. Semin Immunol 1997, 9:315-322.

46. Srivastava P: Interaction of heat shock proteins with peptides and antigen presenting cells: chaperoning of the innate and adaptive immune responses. Annu Rev Immunol 2002, 20:395-425.

47. Jonasch E, Wood C, Tamboli P, Pagliaro LC, Tu SM, Kim J, Srivastava P, Perez C, Isakov L, Tannir N: Vaccination of metastatic renal cell carcinoma patients with autologous tumour-derived vitespen vaccine: clinical findings. Br J Cancer 2008, 98:1336-1341.

48. Wood C, Srivastava P, Bukowski R, Lacombe L, Gorelov Al, Gorelov S, Mulders P, Zielinski H, Hoos A, Teofilovici F, et al: An adjuvant autologous therapeutic vaccine (HSPPC-96; vitespen) versus observation alone for patients at high risk of recurrence after nephrectomy for renal cell carcinoma: a multicentre, open-label, randomised phase III trial. Lancet 2008, 372:145-154

49. Li Z, Qiao Y, Liu B, Laska EJ, Chakravarthi P, Kulko JM, Bona RD, Fang M, Hegde U, Moyo V, et al: Combination of imatinib mesylate with autologous leukocyte-derived heat shock protein and chronic myelogenous leukemia. Clin Cancer Res 2005, 11:4460-4468.

50. Goldstein MG, Li Z: Heat-shock proteins in infection-mediated inflammation-induced tumorigenesis. J Hematol Oncol 2009, 2:5.

51. Basu S, Binder RJ, Ramalingam T, Srivastava PK: CD91 is a common receptor for heat shock proteins gp96, hsp90, hsp70, and calreticulin. Immunity 2001, 14:303-313.

52. Li Z, Nash JD, Qiao Y, Kulko JM, Wilcox DK, Gaffney J, Runowicz CD, Simonich SA, Liu B, Srivastava PK: An autologous tumor-derived heat shock protein vaccine for high risk ovarian cancer. Proc Am Soc Clin Oncol J Clin Oncol 2005, 23:9592.

53. Qiao Y, Liu B, Li Z: Activation of NK cells by extracellular heat shock protein 70 through induction of NKG2D ligands on dendritic cells. Cancer Immun 2008, 8:12

54. Nagaraj S, Gabrilovich DI: Tumor escape mechanism governed by myeloid-derived suppressor cells. Cancer Res 2008, 68:2561-2563.

55. Sica A, Bronte V: Altered macrophage differentiation and immune dysfunction in tumor development. J Clin Invest 2007, 117:1155-1166.

56. Nagaraj S, Gabrilovich DI: Myeloid-derived suppressor cells. Adv Exp Med Biol 2007, 601:213-223.

57. Hensler $\mathrm{T}$, Hecker $\mathrm{H}$, Heeg $\mathrm{K}$, Heidecke CD, Bartels $\mathrm{H}$, Barthlen W, Wagner $\mathrm{H}$ Siewert JR, Holzmann B: Distinct mechanisms of immunosuppression as a consequence of major surgery. Infect Immun 1997, 65:2283-2291.

58. Brune IB, Wilke W, Hensler T, Holzmann B, Siewert JR: Downregulation of T helper type 1 immune response and altered pro-inflammatory and antiinflammatory $T$ cell cytokine balance following conventional but not laparoscopic surgery. Am J Surg 1999, 177:55-60.

59. Chen Y, Lim BK, Hashim OH: Different altered stage correlative expression of high abundance acute-phase proteins in sera of patients with epithelial ovarian carcinoma. J Hematol Oncol 2009, 2:37.

60. Jager E, Ringhoffer M, Dienes HP, Arand M, Karbach J, Jager D, Ilsemann C, Hagedorn M, Oesch F, Knuth A: Granulocyte-macrophage-colonystimulating factor enhances immune responses to melanoma-associated peptides in vivo. Int I Cancer 1996, 67:54-62.

61. Cormier JN, Salgaller ML, Prevette T, Barracchini KC, Rivoltini L, Restifo NP, Rosenberg SA, Marincola FM: Enhancement of cellular immunity in melanoma patients immunized with a peptide from MART-1/Melan A. Cancer J Sci Am 1997, 3:37-44.

62. Rosenberg SA, Yang JC, Schwartzentruber DJ, Hwu P, Marincola FM, Topalian SL, Restifo NP, Dudley ME, Schwarz SL, Spiess PJ, et al: Immunologic and therapeutic evaluation of a synthetic peptide vaccine for the treatment of patients with metastatic melanoma. Nat Med 1998, 4:321-327.

63. Gnjatic S, Cai Z, Viguier M, Chouaib S, Guillet JG, Choppin J: Accumulation of the p53 protein allows recognition by human CTL of a wild-type p53 epitope presented by breast carcinomas and melanomas. I Immunol 1998, 160:328-333.
64. Svane IM, Pedersen AE, Johnsen HE, Nielsen D, Kamby C, Gaarsdal E, Nikolajsen K, Buus S, Claesson MH: Vaccination with p53-peptide-pulsed dendritic cells, of patients with advanced breast cancer: report from a phase I study. Cancer Immunol Immunother 2004, 53:633-641.

65. Carbone DP, Ciernik IF, Kelley MJ, Smith MC, Nadaf S, Kavanaugh D, Maher VE, Stipanov M, Contois D, Johnson BE, et al: Immunization with mutant p53- and K-ras-derived peptides in cancer patients: immune response and clinical outcome. J Clin Oncol 2005, 23:5099-5107.

66. Gjertsen MK, Buanes T, Rosseland AR, Bakka A, Gladhaug I, Soreide O, Eriksen JA, Moller M, Baksaas I, Lothe RA, et al: Intradermal ras peptide vaccination with granulocyte-macrophage colony-stimulating factor as adjuvant: Clinical and immunological responses in patients with pancreatic adenocarcinoma. Int $J$ Cancer 2001, 92:441-450

67. Marchand M, van Baren N, Weynants P, Brichard V, Dreno B, Tessier MH, Rankin E, Parmiani G, Arienti F, Humblet $Y$, et al: Tumor regressions observed in patients with metastatic melanoma treated with an antigenic peptide encoded by gene MAGE-3 and presented by HLA-A1. Int J Cancer 1999, 80:219-230.

68. Karanikas V, Hwang LA, Pearson J, Ong CS, Apostolopoulos V, Vaughan H, Xing PX, Jamieson G, Pietersz G, Tait B, et al: Antibody and T cell responses of patients with adenocarcinoma immunized with mannanMUC1 fusion protein. J Clin Invest 1997, 100:2783-2792.

69. Yin BW, Dnistrian A, Lloyd KO: Ovarian cancer antigen CA125 is encoded by the MUC16 mucin gene. Int J Cancer 2002, 98:737-740.

70. Berek JS, Taylor PT, Gordon A, Cunningham MJ, Finkler N, Orr J Jr, Rivkin S, Schultes BC, Whiteside TL, Nicodemus CF: Randomized, placebo-controlled study of oregovomab for consolidation of clinical remission in patients with advanced ovarian cancer. J Clin Oncol 2004, 22:3507-3516.

71. Rebischung C, Pautier P, Morice P, Lhomme C, Duvillard P: Alphafetoprotein production by a malignant mixed Mullerian tumor of the ovary. Gynecol Oncol 2000, 77:203-205.

72. McAneny D, Ryan CA, Beazley RM, Kaufman HL: Results of a phase I trial of a recombinant vaccinia virus that expresses carcinoembryonic antigen in patients with advanced colorectal cancer. Ann Surg Oncol 1996, 3:495-500

73. Sanda MG, Smith DC, Charles LG, Hwang C, Pienta KJ, Schlom J, Milenic D, Panicali D, Montie JE: Recombinant vaccinia-PSA (PROSTVAC) can induce a prostate-specific immune response in androgen-modulated human prostate cancer. Urology 1999, 53:260-266.

74. Borysiewicz LK, Fiander A, Nimako M, Man S, Wilkinson GW Westmoreland D, Evans AS, Adams M, Stacey SN, Boursnell ME, et al: A recombinant vaccinia virus encoding human papillomavirus types 16 and 18, E6 and E7 proteins as immunotherapy for cervical cancer. Lancet 1996, 347:1523-1527.

75. Noujaim AA, Schultes BC, Baum RP, Madiyalakan R: Induction of CA125specific $B$ and $T$ cell responses in patients injected with MAb-B43.13evidence for antibody-mediated antigen-processing and presentation of CA125 in vivo. Cancer Biother Radiopharm 2001, 16:187-203.

76. Berek JS, Taylor PT, Nicodemus CF: CA125 velocity at relapse is a highly significant predictor of survival post relapse: results of a 5-year followup survey to a randomized placebo-controlled study of maintenance oregovomab immunotherapy in advanced ovarian cancer. J Immunother 2008, 31:207-214

77. Wagner U, Kohler S, Reinartz S, Giffels P, Huober J, Renke K, Schlebusch H, Biersack HJ, Mobus V, Kreienberg R, et al: Immunological consolidation of ovarian carcinoma recurrences with monoclonal anti-idiotype antibody ACA125: immune responses and survival in palliative treatment. See The biology behind: K. A. Foon and M. Bhattacharya-Chatterjee, Are solid tumor anti-idiotype vaccines ready for prime time?. Clin Cancer Res 2001, 7:1112-1115.

78. Bookman MA, Darcy KM, Clarke-Pearson D, Boothby RA, Horowitz IR: Evaluation of monoclonal humanized anti-HER2 antibody, trastuzumab, in patients with recurrent or refractory ovarian or primary peritoneal carcinoma with overexpression of HER2: a phase II trial of the Gynecologic Oncology Group. J Clin Oncol 2003, 21:283-290.

79. Agus DB, Gordon MS, Taylor C, Natale RB, Karlan B, Mendelson DS, Press MF, Allison DE, Sliwkowski MX, Lieberman G, et al: Phase I clinical study of pertuzumab, a novel HER dimerization inhibitor, in patients with advanced cancer. J Clin Oncol 2005, 23:2534-2543. 
80. Nicholson S, Bomphray CC, Thomas H, Mclndoe A, Barton D, Gore M, George AJ: A phase I trial of idiotypic vaccination with HMFG1 in ovarian cancer. Cancer Immunol Immunother 2004, 53:809-816.

81. Nicholson S, Gooden CS, Hird V, Maraveyas A, Mason P, Lambert HE, Meares CF, Epenetos AA: Radioimmunotherapy after chemotherapy compared to chemotherapy alone in the treatment of advanced ovarian cancer: a matched analysis. Oncol Rep 1998, 5:223-226.

82. Jager $E$, Gnjatic $S$, Nagata Y, Stockert E, Jager D, Karbach J, Neumann A, Rieckenberg J, Chen YT, Ritter G, et al: Induction of primary NY-ESO-1 immunity: CD8+ T lymphocyte and antibody responses in peptidevaccinated patients with NY-ESO-1+ cancers. Proc Natl Acad Sci USA 2000, 97:12198-12203.

83. Odunsi K, Qian F, Matsuzaki J, Mhawech-Fauceglia P, Andrews C, Hoffman EW, Pan L, Ritter G, Villella J, Thomas B, et al: Vaccination with an NY-ESO-1 peptide of HLA class I/II specificities induces integrated humoral and T cell responses in ovarian cancer. Proc Natl Acad Sci USA 2007, 104:12837-12842.

84. Edwards RP, Gooding W, Lembersky BC, Colonello K, Hammond R, Paradise C, Kowal CD, Kunschner AJ, Baldisseri M, Kirkwood JM, Herberman RB: Comparison of toxicity and survival following intraperitoneal recombinant interleukin-2 for persistent ovarian cancer after platinum: twenty-four-hour versus 7-day infusion. J Clin Oncol 1997, 15:3399-3407.

85. Berek JS, Hacker NF, Lichtenstein A, Jung T, Spina C, Knox RM, Brady J, Greene $T$, Ettinger $L M$, Lagasse $L D$, et al: Intraperitoneal recombinant alpha-interferon for "salvage" immunotherapy in stage III epithelial ovarian cancer: a Gynecologic Oncology Group Study. Cancer Res 1985, 45:4447-4453.

86. Berek JS, Markman M, Blessing JA, Kucera PR, Nelson BE, Anderson B, Hanjani P: Intraperitoneal alpha-interferon alternating with cisplatin in residual ovarian carcinoma: a phase II Gynecologic Oncology Group study. Gynecol Oncol 1999, 74:48-52.

87. Berek JS, Markman M, Stonebraker B, Lentz SS, Adelson MD, DeGeest K, Moore D: Intraperitoneal interferon-alpha in residual ovarian carcinoma: a phase II gynecologic oncology group study. Gynecol Oncol 1999, 75:10-14.

88. Allavena P, Peccatori F, Maggioni D, Erroi A, Sironi M, Colombo N, Lissoni A, Galazka A, Meiers W, Mangioni C, et al: Intraperitoneal recombinant gamma-interferon in patients with recurrent ascitic ovarian carcinoma: modulation of cytotoxicity and cytokine production in tumor-associated effectors and of major histocompatibility antigen expression on tumor cells. Cancer Res 1990, 50:7318-7323.

89. Pujade-Lauraine E, Guastalla JP, Colombo N, Devillier P, Francois E, Fumoleau P, Monnier A, Nooy M, Mignot L, Bugat R, et al: Intraperitoneal recombinant interferon gamma in ovarian cancer patients with residual disease at second-look laparotomy. J Clin Oncol 1996, 14:343-350.

90. Hernando JJ, Park TW, Kubler K, Offergeld R, Schlebusch H, Bauknecht T: Vaccination with autologous tumour antigen-pulsed dendritic cells in advanced gynaecological malignancies: clinical and immunological evaluation of a phase I trial. Cancer Immunol Immunother 2002, 51:45-52.

91. Hernando JJ, Park TW, Fischer HP, Zivanovic O, Braun M, Polcher M, Grunn U, Leutner C, Potzsch B, Kuhn W: Vaccination with dendritic cells transfected with mRNA-encoded folate-receptor-alpha for relapsed metastatic ovarian cancer. Lancet Oncol 2007, 8:451-454.

92. Homma S, Sagawa Y, Ito M, Ohno T, Toda G: Cancer immunotherapy using dendritic/tumour-fusion vaccine induces elevation of serum antinuclear antibody with better clinical responses. Clin Exp Immunol 2006, 144:41-47.

doi:10.1186/1756-8722-3-7

Cite this article as: Liu et al:: Ovarian cancer immunotherapy:

opportunities, progresses and challenges. Journal of Hematology \& Oncology 2010 3:7.

\section{Submit your next manuscript to BioMed Central and take full advantage of:}

- Convenient online submission

- Thorough peer review

- No space constraints or color figure charges

- Immediate publication on acceptance

- Inclusion in PubMed, CAS, Scopus and Google Scholar

- Research which is freely available for redistribution

Submit your manuscript at www.biomedcentral.com/submit 